\title{
Produksi Material Enrico-Fermi (Memperkaya Kandungan Nitrogen Pada Pupuk Organik Dari Hasil Produk Samping Penyulingan Minyak Nilam)
}

\author{
Novia Arisni ${ }^{1}$, Riana Tania ${ }^{2}$, Izarul Machdar ${ }^{3}$, Umi Fathanah $^{4}$ \\ 1,2,3,4 Program Studi Teknik Kimia, Fakultas Teknik, Universitas Syiah Kuala, Banda Aceh \\ *Koresponden email: noviaarisni1 @ gmail.com
}

Diterima: 30 Juli 2021

Disetujui: 7 Agustus 2021

\begin{abstract}
The use of distilled patchouli waste is still very limited and should be optimized, research is carried out on the manufacture of granule compost from patchouli solid waste through 3 stages of activity. The first aerobic fermentation process of Aceh Jaya patchouli solid waste with variations in the ratio between patchouli solid waste and industrial liquid tofu waste used, i.e., 1:1; 1:3; and 1:5, then the ratio between waste and bio activator EM4 is 1:3\%; $1: 5 \%$; and 1:7\%. The second Enrico-Fermi fertilizer granulation process using granule adhesive, namely tapioca flour with the ratio of Enrico-Fermi fertilizer to adhesive material is $2: 1$. The three test procedures of the Enrico-Fermi material on the growth of patchouli plants . The results showed that the highest NPK content in the Enrico-Fermi fertilizer was determined by the ratio of patchouli waste to liquid tofu waste, i.e., 1:3 and the addition of EM4 with EM-4 concentrations of $7 \%$, i.e., $5.83 \%$ nitrogen, $1.91 \%$ phosphorus, and $3.46 \%$ potassium. The yield of the granule fertilizer Enrico-Fermi was $71.43 \%$. The response of the plants to the Enrico-Fermi fertilizer caused an increase in the height of the plant stem of $5.7 \mathrm{~cm}, 16$ leaves, and 3 branches.
\end{abstract}

Keywords: Patchouli solid waste, Enrico-Fermi fertilizer, nitrogen, tofu industrial wastewater, EM4

\section{Abstrak}

Pemanfaatan limbah nilam hasil penyulingan masih sangat terbatas sehingga untuk mengoptimalkannya dilakukan penelitian pembuatan pupuk kompos granul dari limbah padat nilam melalui 3 tahapan kegiatan. Pertama proses fermentasi aerobik limbah padat nilam Aceh Jaya dengan variasi rasio limbah padat nilam dan limbah cair industri tahu yang digunakan yaitu $1: 1 ; 1: 3$; dan 1:5 kemudian rasio antara limbah dan bioaktivator EM4 yaitu 1:3\%; 1:5\%; dan 1:7\%. Kedua proses granulasi pupuk Enrico-Fermi dengan menggunakan bahan perekat granul yaitu tepung tapioka dengan rasio antara pupuk Enrico-Fermi dan bahan perekat yaitu 2:1. Ketiga proses pengujian material Enrico-Fermi terhadap pertumbuhan tanaman nilam. Hasil penelitian menunjukkan kandungan NPK tertinggi pada pupuk Enrico-Fermi diperoleh pada rasio antara limbah nilam dan limbah cair tahu yaitu 1:3 serta penambahan EM4 dengan konsentrasi EM4 $7 \%$ yaitu nitrogen sebesar 5,83\%, phosfor $1,91 \%$ dan kalium 3,46\%. Diperoleh yield pupuk granul EnricoFermi yaitu sebesar $71,43 \%$. Respon tanaman terhadap pupuk Enrico-Fermi menghasilkan penambahan tinggi batang tanaman $5,7 \mathrm{~cm}$, jumlah daun 16 buah, dan cabang 3 buah.

Kata kunci: limbah padat nilam, pupuk Enrico-Fermi, nitrogen, limbah cair industri tahu, EM4

\section{Pendahuluan}

Minyak nilam merupakan hasil penyulingan dari tanaman nilam yang telah dikeringkan (berupa campuran ranting dan daun). Selain minyak yang menjadi produk utamanya, proses ini juga menghasilkan limbah padat nilam yang cukup banyak, karena yield minyak yang dihasilkan hanya berkisar 1,2-3\%, sehingga limbah yang dihasilkan sekitar 97-98,8\% [1]. Kandungan hara terkhusus nitrogen pada kompos limbah nilam dapat mencapai 3,59\% [2]. Kandungan nitrogen yang tinggi pada kompos limbah nilam menjadikan penerapan pupuk organik limbah padat nilam sangat efektif untuk meningkatkan kesuburan tanah dan meningkatkan pertumbuhan tanaman nilam. Pengomposan merupakan salah satu teknologi pengolahan limbah padat yang mengandung bahan organik biodegradable (yang dapat diuraikan oleh mikroorganisme). Fermentasi adalah proses penguraian bahan organik, yang dilakukan dengan cara memfermentasi mikroorganisme dalam kondisi tertentu [3]. Proses fermentasi pada penelitian ini digunakan untuk mengubah limbah padat nilam menjadi pupuk organik dengan bantuan bioaktivator pada tahap fermentasi aerob. Dalam proses ini banyak koloni bakteri yang berperan, sehingga digunakan bioaktivator EM4 yang terdiri dari beberapa jenis bakteri yang dibutuhkan untuk membuat kompos. Pada penelitian ini akan digunakan bahan lain berupa limbah cair tahu. Proses fermentasi yang biasanya 
memakan waktu 2-6 bulan, sehingga dengan adanya bantuan mikroorganisme berupa EM4 proses dapat dipercepat menjadi 10 hari [4]. Limbah cair tahu dapat digunakan sebagai pengganti baru untuk pupuk tanaman, karena limbah cair tahu memiliki unsur hara yang dibutuhkan oleh tanaman. Unsur hara pada limbah cair tahu dapat digunakan sebagai pupuk organik cair. Nutrisi yang terkandung dalam limbah cair tahu murni adalah $\mathrm{N}$ total $1,24 \%, \mathrm{P}_{2} \mathrm{O}_{5}$ (fosfor) $5,54 \%$ dan $\mathrm{K}_{2} \mathrm{O}$ (kalium) $1,34 \%$ [5].

Harapan utama dalam proses pembuatan pupuk kompos yang dilakukan adalah untuk menyelesaikan permasalahan limbah penyulingan minyak nilam yang berupa ampas daun dan batang nilam. Penggunaan pupuk organik dapat menggantikan permasalahan lingkungan yang diakibatkan oleh penggunaan pupuk kimia. Masyarakat juga semakin banyak menggunakan dan menjual pupuk organik. Mahalnya biaya energi untuk membuat pupuk membuat harga pupuk buatan menjadi mahal. Oleh karena itu, perlu dicari sumber alternatif lain untuk memperbaiki sistem produksi pupuk organik. Salah satu sumber potensial adalah pupuk organik yang tersedia secara lokal [6].

Tujuan dari penelitian ini adalah untuk mendapatkan formulasi pupuk kompos granul yang diperkaya nitrogen dengan penambahan limbah cair industri tahu sebagai sumber nitrogen organik serta rasio penggunaan bioaktivator EM4 terhadap kualitas pupuk granul organik yang dihasilkan.

\section{Metode Penelitian}

\section{Tempat dan Waktu Penelitian}

Penelitian ini dilakukan dari bulan Agustus 2019 sampai Maret 2020 di Laboratorium Instrumentasi dan Analisis Jurusan Teknik Kimia. Analisa dilakukan di Laboratorium Fisika Material FMIPA Unsyiah, Laboratorium Teknik Lingkungan Unsyiah, dan Laboratorium Tanah dan Tanaman Unsyiah.

\section{Alat dan Bahan}

Peralatan yang digunakan adalah gunting pencacah, ayakan berukuran 6 mesh, drum pengomposan, wadah multiguna, timbangan analitik, gelas ukur $100 \mathrm{ml}$ dan $250 \mathrm{ml}$, Fourier Transform InfraRed (FTIR) Shimadzu 8400s, X-Ray Diffraction (XRD), Atomic Absorption Spectrofotometer (AAS), Spektrofotometer $U V$-Vis, Metode Kjeldahl.

Bahan-bahan yang digunakan dalam penelitian ini antara lain limbah padat penyulingan nilam, limbah cair industri tahu, bioaktivator EM-4, tepung tapioka dan aquades.

\section{Prosedur Penelitian}

\section{Pembuatan Pupuk Granul Enrico-Fermi}

Pembuatan pupuk granul Enrico-Fermi diawali dengan penyiapan bahan baku terdiri dari penyiapan limbah padat industri nilam, limbah cair industri tahu dengan rasio antara limbah nilam dan limbah cair tahu yaitu $1: 1 ; 1: 3$; dan 1:5, serta bioaktivator EM4 dengan rasio antara limbah dan bioaktivator yaitu 1:3\%; 1:5\%; dan 1:7\% serta bahan perekat granul yaitu tepung tapioka dengan rasio antara bahan perekat dan pupuk kompos Enrico-Fermi yaitu 1:2. Material limbah padat nilam diambil dari salah satu lokasi penyulingan minyak nilam di Kabupaten Aceh Jaya, sedangkan bioaktivator EM4 diperoleh dari hasil sampling random sederhana dan limbah cair tahu diperoleh dari industri tahu di Banda Aceh. Untuk menghasilkan granul, akan proses pembuatan granul secara sederhana dengan memanfaatkan nampan atau wadah berukuran tertentu.

Tahapan penelitian dimulai dari limbah padat yang telah dikeringkan lalu dipisahkan antara batang, ranting, dan daunnya. Selanjutnya daun limbah nilam akan dihancurkan dengan gunting pencacah, kemudian dilakukan proses fermentasi aerobik dengan penambahan limbah cair industri tahu dengan rasio antara limbah nilam dan bantuan bioaktivator EM4 selama 20 hari hingga terbentuk kompos organik dengan 9 sampel yang berbeda. Selanjutnya kompos organik yang masih berbentuk serbuk diolah menjadi bentuk granul dengan penambahan tepung tapioka sebagai bahan perekatnya. Granul yang dihasilkan kemudian diayak dengan ayakan berukuran 6 mesh sehingga didapatkan ukuran granul sebesar $3 \mathrm{~mm}$, granul dengan ukuran $<3$ dan $>3 \mathrm{~mm}$ dilakukan recycle ke tahap penghancuran kembali. Analisis komposisi produk pupuk Enrico-Fermi dilakukan sesuai dengan Standar Nasional Indonesia nomor 19-7-30-2004 dan Peraturan Menteri Pertanian No.70/Permentan/SR.140/10/2011.

\section{Analisis Persentase Intensitas Spektra N, P, dan K Limbah Nilam}

Limbah nilam yang diperoleh dari tempat penyulingan diidentifikasi persentase intensitas spektra NPK nya menggunakan instrumen X-Ray Diffraction (XRD) untuk menganalisa bahan apa yang terkandung di dalam sampel limbah padat nilam yang dapat ditentukan secara kuantitatif dengan metode analisa search-match [7]. 


\section{Identifikasi Gugus Fungsi}

Pupuk granul Enrico-Fermi yang telah dihasilkan diidentifikasi gugus fungsinya menggunakan instrumen Fourier Transform Infrared Spectroscopy (FTIR) untuk mengidentifikasi material di dalam produk.

\section{Pengujian Kualitas Pupuk}

Pengujian produk pupuk granul Enrico-Fermi terdiri dari pengujian kualitas kimia dan pengujian terhadap tanaman. Pengujian kualitas kimia meliputi Nitrogen total, P2O5, dan K2O. kadar Nitrogen total dianalisa dengan menggunakan metode Kjedahl, P2O5 dianalisa dengan menggunakan spektrofotometri UV-VIS, dan K2O dianalisa dengan menggunakan AAS. Hasil pengujian kualitas kimia pupuk dibandingkan dengan standar kualitas kompos menurut Standar Nasional Indonesia nomor 19-7-30-2004.

Pengujian terhadap tanaman dilakukan dengan menggunakan 3 perlakuan yaitu menggunakan limbah padat nilam, pupuk Enrico-Fermi dengan penambahan limbah cair industri tahu, dan kontrol (hanya tanah). Setiap 3 hari sekali dilakukan pengamatan kualitas tanaman yaitu diukur jumlah cabang, jumlah daun, dan tinggi batang tanaman.

\section{Analisis Data Perolehan Yield Pupuk Granul Enrico-Fermi}

Pengujian yield dilakukan degan menggunakan saringan berdiameter $3 \mathrm{~mm}$ dan $5 \mathrm{~mm}$. Granul yang lolos pada saringan $5 \mathrm{~mm}$ dan granul yang tertahan pada saringan $3 \mathrm{~mm}$ keduanya dilakukan penimbangan. Yield pupuk organik granul dapat dihitung dengan menggunakan rumus pada persamaan 1:

Dimana:

$$
\text { Yield pupuk }(\%)=\frac{\mathrm{w}_{\mathrm{o}}}{\mathrm{W}} \times 100 \%
$$

$\mathrm{W}_{\mathrm{o}}=$ berat pupuk organik granul yang diuji $(\mathrm{g})$

$\mathrm{W}=$ berat pupuk organik granul yang tertahan pada saringan $3 \mathrm{~mm}$ dan lolos pada saringan $5 \mathrm{~mm}(\mathrm{~g})$

\section{Hasil dan Pembahasan}

\section{Analisis Persentase Intensitas Spektra N, P, dan K Menggunakan X-Ray Diffraction}

Pengujian XRD (X-Ray Diffraction) dilakukan untuk menganalisa bahan apa yang terkandung di dalam sampel limbah padat nilam yang dapat ditentukan secara kuantitatif dengan metode analisa searchmatch. Adapun persentase intensitas spektra N, P, dan K pada limbah padat nilam dapat dilihat pada Tabel 1 dan Gambar 1.

Tabel 1. Persentase intensitas spektra N, P, dan K pada limbah padat nilam

\begin{tabular}{lcc}
\hline \multicolumn{1}{c}{ Komposisi } & Satuan & Jumlah \\
\hline Nitrogen & $\%$ & 70,4 \\
Phosfor $\left(\mathrm{P}_{2} \mathrm{O}_{5}\right)$ & $\%$ & 18,2 \\
Kalium $\left(\mathrm{K}_{2} \mathrm{O}\right)$ & $\%$ & 11,4 \\
\hline \multicolumn{2}{c}{ Sumber : Hasil pengujian penelitian, (2019) }
\end{tabular}

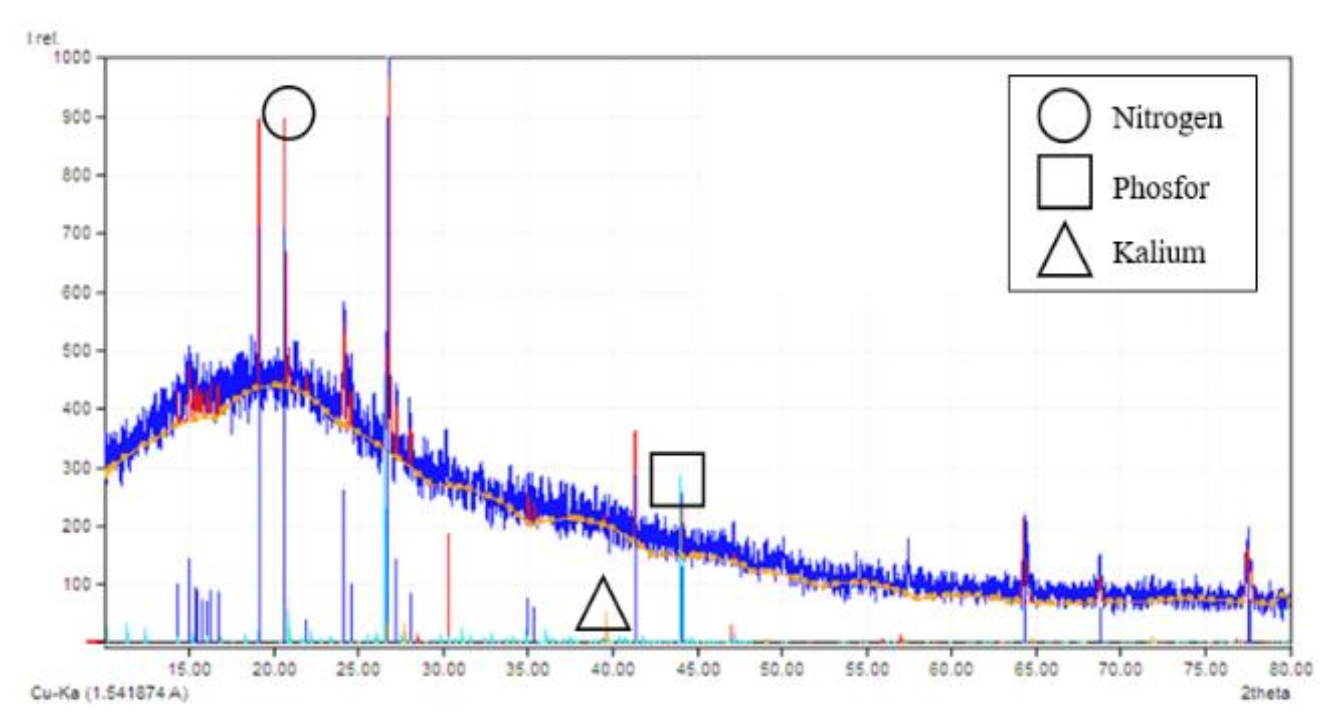

Gambar 1. XRD profil untuk sampel limbah padat nilam Sumber : Hasil pengujian penelitian, (2020) 
Berdasarkan Gambar 1 dan Tabel 1 dapat dilihat hasil pembacaan X-Ray Diffraction (XRD) bahwa sampel limbah padat nilam mengandung unsur N, P, dan K dengan persentase intensitas spektra berturutturut yaitu $70,4 \% ; 18,2 \%$; dan $11,4 \%$.

Identifikasi Gugus Fungsi Menggunakan Fourier Transform Infrared Spectroscopy (FTIR)

Fourier Transform Infrared Spectroscopy (FTIR) merupakan suatu metode spektroskopi infra merah. Instrumen ini dapat digunakan untuk mengidentifikasi material yang tidak diketahui, menentukan kualitas atau konsistensi suatu sampel, dan menghitung jumlah komponen di dalam suatu campuran [8]. Analisis gugus fungsi pada limbah padat nilam dan pupuk Enrico-Fermi bertujuan untuk mengetahui gugus fungsi pada sampel. Spektrum limbah padat nilam dan pupuk Enrico-Fermi yang telah diperoleh dapat dilihat pada Gambar 2.

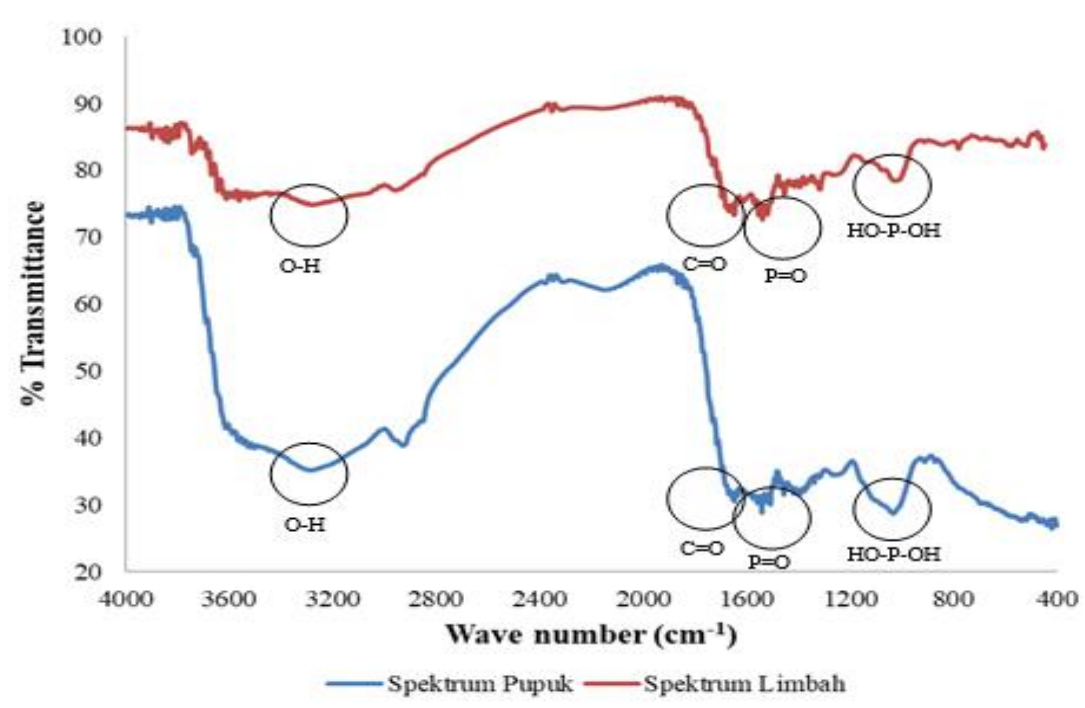

Gambar 2. Spektrum limbah padat nilam dan pupuk Enrico-Fermi Sumber : Hasil pengujian penelitian, (2020)

Gambar 2 menunjukkan hasil pembacaan FTIR bahwa pada rentang 3.200-3.300 cm-1 spektrum limbah padat nilam sebelum ditambahkan limbah cair industri tahu dan EM-4 terdapat gugus O-H, sementara pada pupuk Enrico-Fermi setelah ditambahkan limbah tahu dan EM-4 juga terindikasi adanya gugus O-H. Pada rentang 1600-1760 cm-1 spektrum limbah padat nilam sebelum ditambahkan limbah cair industri tahu dan EM-4 terdapat gugus $\mathrm{C}=\mathrm{O}$, sementara pada pupuk Enrico-Fermi setelah ditambahkan limbah tahu dan EM-4 terindikasi adanya gugus $\mathrm{C}=\mathrm{O}$. Pada rentang 1000-1500 cm-1 spektrum limbah padat nilam sebelum ditambahkan limbah cair industri tahu dan EM-4 terdapat gugus $\mathrm{P}=\mathrm{O}$ dan $\mathrm{HO}-\mathrm{P}-\mathrm{OH}$, begitu pula pada pupuk Enrico-Fermi setelah ditambahkan limbah tahu dan EM-4.

Analisis Produk Material Enrico-Fermi Dengan Penambahan Limbah Cair Industry Tahu dan Bioaktivator Effective Microorganism 4 (EM4)

Pengujian nitrogen, fosfor, dan kalium dilakukan pada produk pupuk Enrico-Fermi menggunakan limbah cair industri tahu dan EM-4 yang terdiri atas 9 sampel uji dengan perlakuan yang berbeda-beda. Kadar nitrogen, fosfor, dan kalium pada pupuk Enrico-Fermi dapat dilihat pada Tabel 2, serta perbandingan kompos nilam yang dihasilkan dengan beberapa kompos organik lainnya dapat dilihat pada Tabel 3.

Tabel 2. Hasil pengujian pupuk Enrico-Fermi

\begin{tabular}{ccccc}
\hline Limbah (nilam : tahu) & Limbah : EM-4 & $\mathrm{N}(\%)$ & $\mathrm{P}_{2} \mathrm{O}_{5}(\%)$ & $\mathrm{K}_{2} \mathrm{O}(\%)$ \\
\hline \multirow{2}{*}{$1: 1$} & $1: 3 \%$ & 3,60 & 1,03 & 2,66 \\
& $1: 5 \%$ & 3,65 & 0,77 & 2,03 \\
$1: 7 \%$ & 4,68 & 1,14 & 1,68 \\
\multirow{2}{*}{$1: 3$} & $1: 3 \%$ & 5,75 & 0,81 & 4,24 \\
& $1: 5 \%$ & 5,72 & 1,14 & 3,17 \\
\multirow{2}{*}{$1: 5$} & $1: 7 \%$ & 5,83 & 1,91 & 3,46 \\
& $1: 3 \%$ & 4,78 & 0,96 & 2,46 \\
& $1: 5 \%$ & 4,76 & 0,92 & 2,94 \\
\hline
\end{tabular}

Sumber: Hasil pengujian penelitian, (2020) 
Tabel 3. Perbandingan pupuk Enrico-Fermi dengan kompos Standar Nasional Indonesia

\begin{tabular}{lcccc}
\hline \multirow{2}{*}{ Parameter } & \multirow{2}{*}{ Satuan } & $\begin{array}{c}\text { Pupuk Enrico-Fermi } \\
\text { Sampel }(1: 3: 7 \%)\end{array}$ & \multicolumn{2}{c}{ SNI (19-7-30-2004) } \\
\hline N Total & $\%$ & 5,83 & 0,04 & Maks \\
$\mathrm{P}_{2} \mathrm{O}_{5}$ & $\%$ & 1,91 & 0,10 & - \\
$\mathrm{K}_{2} \mathrm{O}$ & $\%$ & 4,24 & 0,20 & - \\
\hline
\end{tabular}

Sumber: SIN ( Nomor 19-70302004 ) dalam Indrawan, Widana, dan Oviantari, 2016 [9]

Berdasarkan Tabel 2 dapat dilihat bahwa kadar nitrogen tertinggi diperoleh dari sampel 6 dengan rasio limbah 1:3 dan konsentrasi EM-4 7\% yaitu sebesar 5,83\%, sedangkan kadar nitrogen terendah diperoleh dari sampel 1 dengan rasio limbah 1:1 dan konsentrasi EM-4 3\% yaitu sebesar 3,60\%, ini menyatakan bahwa keseluruhan sampel pupuk memenuhi standar SNI nomor 19-70302004 yaitu minimal sebesar $0,4 \%$ [10].

Kadar Phosfor (P2O5) tertinggi diperoleh pada sampel 6 dengan rasio limbah 1:3 dan konsentrasi EM-4 7\% yaitu sebesar 1,91\%, sedangkan kadar fosfor terendah diperoleh pada sampel 2 dengan rasio limbah 1:1 dan konsentrasi EM-4 5\% yaitu sebesar 0,77\%, ini menyatakan bahwa keseluruhan sampel pupuk memenuhi standar SNI nomor 19-70302004 yaitu minimal sebesar 0,10\%.

Kadar kalium tertinggi diperoleh dari sampel 4 dengan rasio limbah 1:3 dan konsentrasi EM-4 3\% yaitu sebesar 4,24\%, sedangkan kadar kalium terendah diperoleh dari sampel 2 dengan rasio limbah 1:1 dan konsentrasi EM-4 5\% yaitu sebesar 2,03\%, ini menyatakan bahwa keseluruhan sampel pupuk memenuhi standar SNI nomor 19-70302004 yaitu minimal sebesar 0,20\%.

Pada hasil penelitian yang dilakukan diperoleh nilai NPK tertinggi yaitu sebesar 5,83\%;1,91\% ; dan $4,24 \%$, sedangkan nilai NPK awal limbah yaitu sebesar $1,81 \% ; 0,16 \%$; dan $0,47 \%$. Maka dapat disimpulkan bahwa terjadi peningkatan kadar NPK didalam pupuk Enrico-Fermi, hal ini dapat terjadi dikarenakan adanya pengaruh penambahan limbah cair industri tahu dan penggunaan bioaktivator EM-4 dalam proses pemupukan. EM-4 mengandung bakteri Lactobacillus $s p$. (bakteri penghasil asam laktat), bakteri fotosintetik, dan yeast yang dapat mencerna selullosa, pati, gula, protein, dan lemak [11]. Sehingga adanya penambahan EM-4 pada proses pembuatan pupuk organik dapat meningkatkan kadar NPK pada pupuk dan mempercepat biokonversi limbah organik menjadi biogas, hal ini dikarenakan terjadinya proses dekomposisi bahan kompos oleh organisme yang terdapat pada bioaktivator EM-4 yang mengubah amonia menjadi nitrat [12].

Hubungan antara perubahan tinggi, jumlah daun, dan jumlah cabang tanaman nilam dengan variasi pemberian jenis pupuk diplotkan dalam bentuk grafik. Perubahan tinggi tanaman nilam ditunjukkan pada Gambar 3, perubahan jumlah daun ditunjukkan pada Gambar 4, dan perubahan jumlah cabang pada tanaman ditunjukkan pada Gambar 5.

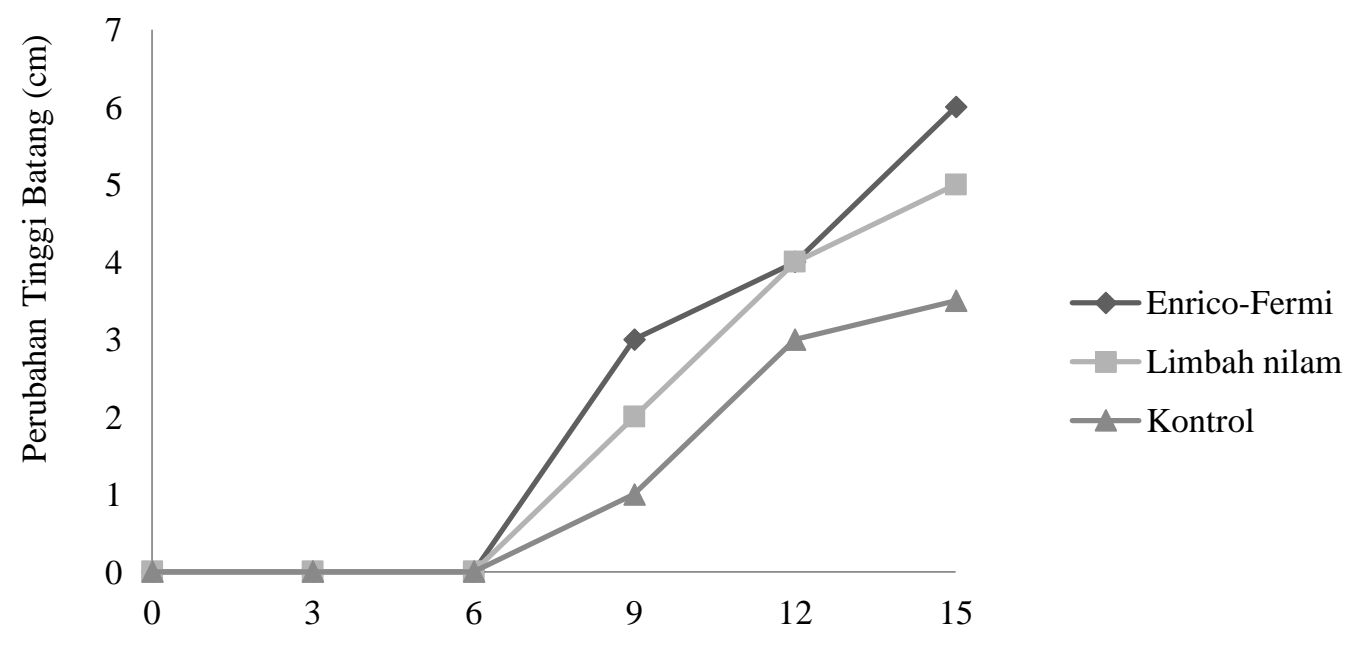

Hari Ke-

Gambar 3. Perubahan tinggi batang tanaman nilam pada setiap perlakuan Sumber: Hasil pengujian penelitian, (2020) 
Pada Gambar 3 menampilkan hubungan antara jenis pupuk dengan pertumbuhan tinggi batang tanaman nilam, dimana tanaman nilam memiliki tinggi yang berbeda-beda pada setiap variasi pupuk yang diberikan. Tanaman nilam tertinggi dihasilkan dari pemberian pupuk Enrico-Fermi dengan tinggi batang $5,7 \mathrm{~cm}$, sedangkan pada pemberian pupuk limbah nilam diperoleh tinggi batang tanaman nilam $5 \mathrm{~cm}$ dan kontrol tanah diperoleh tinggi batang tanaman nilam $3,5 \mathrm{~cm}$.

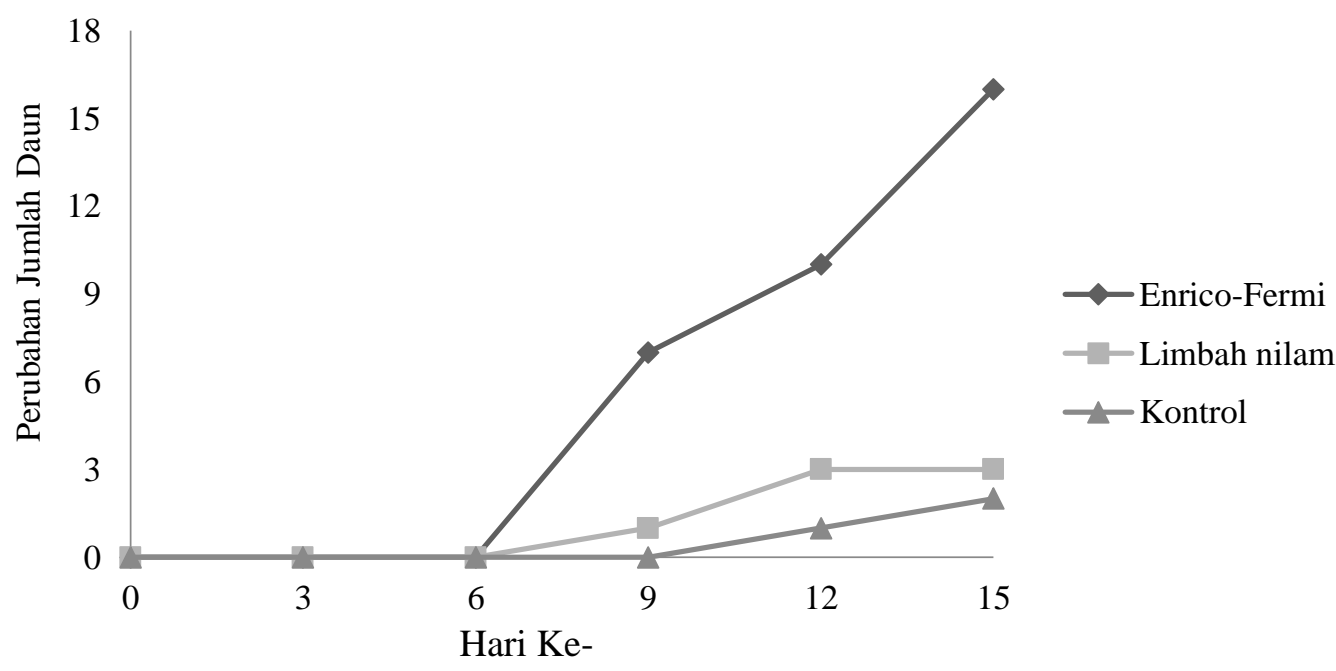

Gambar 4. Perubahan jumlah daun tanaman nilam pada setiap perlakuan Sumber: Hasil pengujian penelitian, (2020)

Pada Gambar 4 menampilkan hubungan antara jenis pupuk dengan jumlah daun tanaman nilam, dimana tanaman nilam memiliki jumlah daun yang berbeda-beda pada setiap variasi pupuk yang diberikan. Jumlah daun terbanyak pada tanaman nilam dihasilkan dari pemberian pupuk Enrico-Fermi dengan jumlah daun sebanyak 16 helai daun, sedangkan pada pemberian pupuk limbah nilam diperoleh jumlah daun sebanyak 3 helai daun dan kontrol tanah diperoleh jumlah daun sebanyak 2 helai daun.

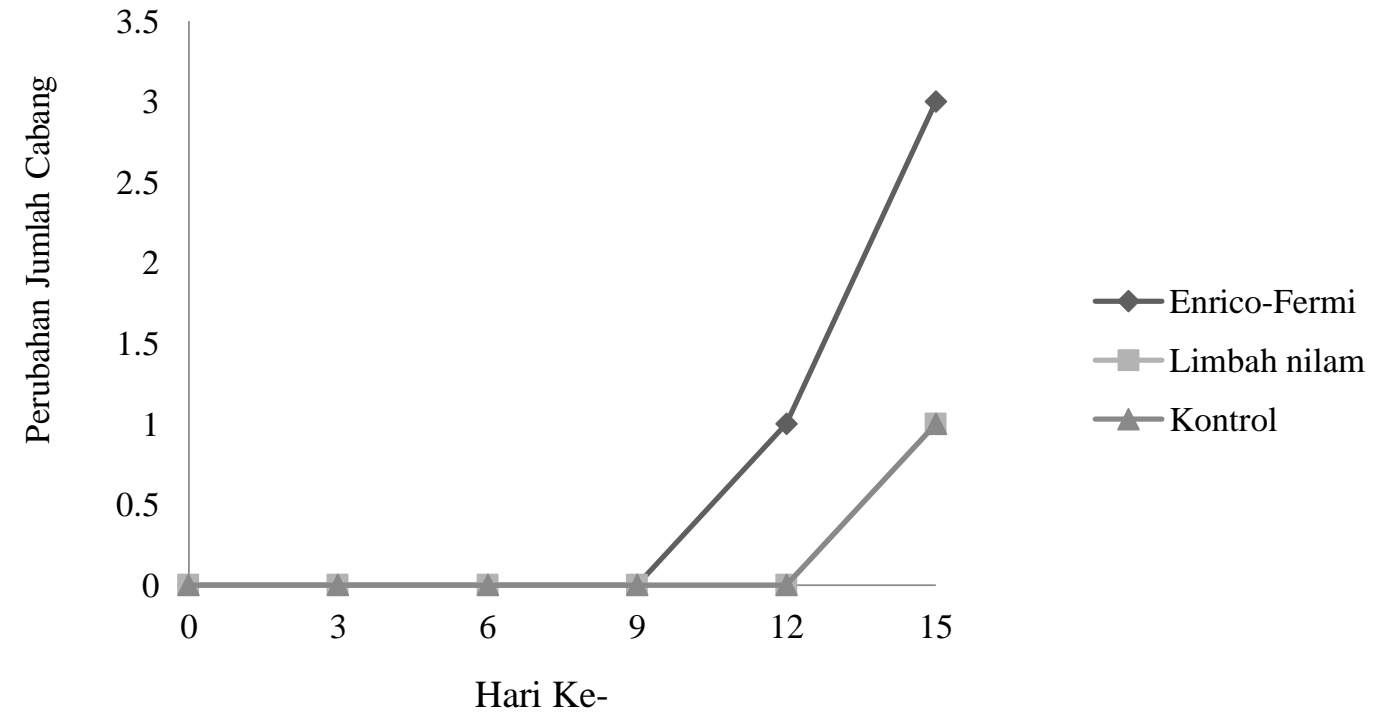

Gambar 5. Perubahan jumlah cabang tanaman nilam pada setiap perlakuan Sumber: Hasil pengujian penelitian, (2020)

Pada Gambar 5 menampilkan hubungan antara jenis pupuk dengan jumlah cabang tanaman nilam, dimana tanaman nilam memiliki jumlah cabang yang berbeda-beda pada setiap variasi pupuk yang diberikan. Jumlah cabang terbanyak pada tanaman nilam dihasilkan dari pemberian pupuk Enrico-Fermi dengan jumlah cabang sebanyak 3 buah cabang, sedangkan pada pemberian pupuk limbah nilam diperoleh 
jumlah cabang sebanyak 1 buah cabang dan kontrol tanah diperoleh jumlah cabang sebanyak 1 buah cabang.

Pada tiga perlakuan yang diberikan kepada setiap tanaman nilam, respon tanaman terhadap penggunaan pupuk Enrico-Fermi menggunakan limbah cair industri tahu dan bioaktivator EM-4 lebih baik dibandingkan dengan respon tanaman dengan menggunakan limbah padat nilam dan kontrol. Hal ini dikarenakan kandungan NPK pada pupuk Enrico-Fermi dengan menggunakan limbah cair tahu dan bioaktivator EM-4 lebih banyak dibandingkan kandungan N pada limbah padat nilam. Dimana peran NPK sangat penting bagi pertumbuhan tanaman agar berkembang secara maksimal. Seperti unsur hara N berfungsi menjadikan tanaman lebih hijau, pertumbuhan tanaman secara keseluruhan menjadi lebih cepat serta meningkatkan kandungan protein pada hasil panen [13]. Unsur hara P berfungsi sebagai pembelahan dan perkembangan jaringan metabolisme tanaman, sehingga dapat memacu pertumbuhan akar, pembungaan dan pemasakan buah [14]. Unsur hara K berfungsi sebagai penyeimbang tanaman bila kelebihan nitrogen, sintesis karbohidrat, meningkatkan tebalan dan kekuatan batang [15].

\section{Data Perolehan Yield Pupuk Granul Enrico-Fermi}

Tujuan dilakukannya pengujian yield yaitu agar diketahui jumlah pupuk organik granul yang berukuran 2-5 mm, hal ini sesuai dengan kriteria pupuk granul Permentan nomor 70/Pert/SR.140/10/2011 [16]. Massa pupuk granul yang dihasilkan dari proses granulasi 210 gram pupuk Enrico-Fermi berbentuk serbuk yaitu sebanyak 150 gram, sehingga berdasarkan hasil perhitungan pada persamaan 1 diperoleh yield pupuk granul Enrico-Fermi yaitu sebesar 71,43\%.

\section{Kesimpulan}

Hasil penelitian menunjukkan bahwa kandungan nitrogen tertinggi pada pupuk Enrico-Fermi diperoleh pada rasio antara limbah nilam dan limbah cair tahu yaitu 1:3 serta penambahan EM-4 dengan konsentrasi EM-4 7\% yaitu sebesar 5,83\%, Phosfor 1,91\% dan Kalium 3,46\%. Hal ini sesuai dengan SNI nomor 19-70302004 dan Permentan nomor 70/Pert/SR.140/10/2011 yang mensyaratkan N, P, dan K minimal $2 \%$. Tepung tapioka dapat dijadikan bahan perekat pada proses granulasi pupuk Enrico-Fermi dengan rasio 1:2 dengan perolehan yield sebesar 71,43\%. Pertumbuhan tanaman nilam dengan menggunakan pupuk Enrico-Fermi jauh lebih cepat dibandingkan dengan tanaman nilam menggunakan limbah padat nilam maupun tanah saja.

\section{Referensi}

[1] B. M. Harahap, A. I. Dewantoro, and M. R. N. Alfajri, "Evaluasi dan perbaikan proses produksi minyak atsiri nilam berbasis neraca massa (Studi kasus CV Anugerah Essential Oil, Sumedang)," J. Ind. Pertan., vol. 01, no. 2, pp. 21-27, 2019, [Online]. Available: http://journal.unpad.ac.id/justin/article/view/22967.

[2] M. Djazuli, "Terhadap Pertumbuhan Dan Produksi Nilam Effect of NPK fertilizer and patchouli waste compost application on growth and productivity of patchouli ( Pogostemon Bent ) peranannya di Indonesia , baik sebagai sumber petani . Dalam proses penyulingan minyak nil," vol. 24 (2), pp. $87-$ 92, 2013.

[3] Y. Suryani, I. Hernaman, and N. Ningsih, "Pengaruh Penambahan Urea Dan Sulfur Pada Limbah Padat Bioetanol Yang Difermentasi Em-4 Terhadap Kandungan Protein Dan Serat Kasar," J. Ilm. Peternak. Terpadu, vol. 5, no. 1, p. 13, 2017, doi: 10.23960/jipt.v5i1.p13-17.

[4] S. Subandriyo, D. D. Anggoro, and H. Hadiyanto, "Optimasi Pengomposan Sampah Organik Rumah Tangga Menggunakan Kombinasi Aktivator Em4 Dan Mol Terhadap Rasio C/N," J. Ilmu Lingkung., vol. 10, no. 2, p. 70, 2012, doi: 10.14710/jil.10.2.70-75.

[5] A. A. Amin, A. E. Yulia, and Nurbaiti, "Pemanfaatan Limbah Cair Tahu Untuk Pertumbuhan Produksi Tanaman Pakcoy (Brassica rapa L.)," vol. 4, no. 13, pp. 379-397, 2017.

[6] I. S. Roidah, "Manfaat Penggunaan Pupuk Organik untuk Kesuburan Tanah," J. Bonorowo, vol. 1, no. 1 , pp. 30-43, 2013.

[7] D. Agustinawati and Suasmoro, "Analisa XRD dan SEM pada Lapisan Tipis TiC Setelah Uji Oksidasi,” J. Tek. Pomits, vol. 3, no. 2, pp. 30-32, 2014.

[8] L. Sjahfirdi, N. Aldi, H. Maheshwari, and P. Astuti, “Aplikasi Fourier Transform Infrared (Ftir) Dan Pengamatan Pembengkakan Genital Pada Spesies Primata, Lutung Jawa (Trachypithecus auratus) Untuk Mendeteksi Masa Subur," J. Kedokt. Hewan - Indones. J. Vet. Sci., vol. 9, no. 2, 2015, doi: 10.21157/j.ked.hewan.v9i2.2837.

[9] I. I. M. Ogik, B. W. G. Agus, and V. O. Made, "Analisis Kadar N, P, K Dalam Pupuk Kompos Produksi TPA Jagaraga Buleleng,” Wahana Mat. dan Sains, vol. 9, pp. 25-31, 2016. 
[10] Badan Standardisasi Nasional, "Spesifikasi kompos dari sampah organik domestik," Badan Stand. Nas., p. 12, 2004.

[11] E. Elpawati, S. D. Dara, and D. Dasumiati, "Optimalisasi Penggunaan Pupuk Kompos dengan Penambahan Effective Microorganism 10 (Em10) pada Produktivitas Tanaman Jagung (Zea mays L.)," AL-Kauniyah J. Biol., vol. 8, no. 2, pp. 77-87, 2016, doi: 10.15408/kauniyah.v8i2.2693.

[12] G. M. Sanjaya, "Biokonversi Sampah Organik Pasar Menjadi Biogas Menggunakan Starter Effective Microorganisms (EM4) Bioconversion of Organic Waste into Biogas by Using Effective Microorganisms Starter (EM 4 )," Sains Mat., vol. 1, no. 1, pp. 17-19, 2016, [Online]. Available: https://journal.unesa.ac.id/index.php/sainsmatematika/article/view/22.

[13] P. S. Patti, E. Kaya, and C. Silahooy, "Analisis Status Nitrogen Tanah Dalam Kaitannya Dengan Serapan N Oleh Tanaman Padi Sawah Di Desa Waimital, Kecamatan Kairatu, Kabupaten Seram Bagian Barat," Agrologia, vol. 2, no. 1, 2018, doi: 10.30598/a.v2i1.278.

[14] L. Trivana and A. Y. Pradhana, "Optimalisasi Waktu Pengomposan dan Kualitas Pupuk Kandang dari Kotoran Kambing dan Debu Sabut Kelapa dengan Bioaktivator PROMI dan Orgadec," J. Sain Vet., vol. 35, no. 1, p. 136, 2017, doi: 10.22146/jsv.29301.

[15] E. Solihin, R. Sudirja, and N. N. Kamaludin, "Pengaruh Dosis Pupuk Kalium terhadap Pertumbuhan dan Peningkatan Hasil Tanaman Jagung Manis (Zea Mays L.) pada Inceptisol," Agrikultura, vol. 30, no. 2, p. 40, 2019, doi: 10.24198/agrikultura.v30i2.22791.

[16] Permentan, "Pupuk Organik, Pupuk Hayati Dan Pembenah Tanah," J. Chem. Inf. Model., vol. 53, no. 9, pp. 21-25, 2017, [Online]. Available: http://www.elsevier.com/locate/scp. 